\title{
sciendo
}

CIVIL AND ENVIRONMENTAL ENGINEERING REPORTS

E-ISSN 2450-8594

CEER 2020; 30 (2): 0133-0157

DOI: $10.2478 /$ ceer-2020-0024

Original Research Article

\section{SOCIO-ECONOMIC ANALYSIS OF RIVERINE FLOODING ON LOW-INCOME DWELLINGS: ADAYAR RIVER, A CASE STUDY}

\author{
Suriya SARAVANAN ${ }^{1}$, Mudgal BASAVARAJ ${ }^{2}$, Prakash NELLIYAT $^{3}$ \\ ${ }^{1}$ Associate Professor, Jerusalem College of Engineering, Chennai, India \\ ${ }^{2}$ Director, Centre for Water Resources, Anna University, Chennai, India \\ ${ }^{3}$ Environmental Economist, National Biodiversity Authority, Chennai
}

\begin{abstract}
Flood damage assessment plays a vital role in providing information to policy developers. Nowadays, due to urbanization, the impact of flooding on communities is extensive, including tangible damage to property, the environment, and infrastructure as well as intangible damage due to stress, health hazards, and hardship. This paper provides an overview of a detailed flood assessment study conducted in the Kotturpuram Housing board area, located on the flood plain of the Adayar River in Chennai, India. A relatively simple approach to data collection was adopted, being a Questionnaire Survey (QS) as well as semi-structured interviews and observation techniques, due to data and research limitations. Losses due to damage to belongings and extra spending to buy essential commodities during flooding are also dealt with in this study. The flood mitigation costs for flooding that occurred in the year 2015 are also evaluated. A stagedamage curve was arrived at based on the information collected. Optimal and sustainable mitigation measures can be achieved only when the socio-economic aspects are adequately considered. Thus, this analysis was designed to estimate the effects of flooding on a community's social and economic welfare, and thereby help to educate the community, including residents and officials, about the impact and magnitude of
\end{abstract}

\footnotetext{
${ }^{1}$ Corresponding author: Associate Professor, Jerusalem College of Engineering, Chennai, India, email: suriya.svu@gmail.com
} 
flooding. The outputs of the study will be the key inputs for designing flood mitigation and relief measures.

Keywords: Adayar river, socio-economic analysis, flood damage, stage-damage curve, TIN

\section{INTRODUCTION}

There is now huge stress on natural resources in urban communities compared to their rural counterparts due to increases in demand for water, energy, and other resources. Researchers are trying to provide innovative solutions to cope up with the constraint on resources but experts believe that climate change will make the situation worse, bringing more severe and frequent floods. Climate change affects people and nature in myriad ways, often increasing existing threats to the environment. Changes in temperature and precipitation due to climate variation have a serious impact on hydrologic processes and have the tendency to increase both the intensity and frequency of floods in many regions of the world [10][18][33]. Climate change may directly alter precipitation and flooding occurs as a consequence of heavy rainfall and anthropogenic activities.

Apart from climate change, the expansion of urban areas combined with rainfall conditions and tidal influences are responsible for the increase in the frequency of urban flooding in coastal cities [9]. This situation is aggravated by a lack of planning and delays in the construction of proper drainage infrastructure. Localized flooding can occur frequently where drainage infrastructure is lacking or deficient [27]. The characteristics of these floods are (i) they can occur for longer or shorter durations with or without warning depending on the flooding type (ii) they can be gradual or sudden and (iii) they may arise purely due to seasonal patterns [7]. The types and degree of remedial measures taken against flooding depend on various topographical, hydrological, and geomorphological factors in addition to the size and socio-economic status of the area. Flood management measures undertaken in the past have not been able to handle the increased water flows due to rapid urbanization and climate change. This gives rise to the need to deal with social concerns and to involve stakeholders in the decision-making process.

The socio-economic analysis of risk perceptions and management strategies underlines the interrelated reasons for floods, which are embedded in a broader context of economic globalization, labour migration, and rapid urbanization. Flood risks have to be reduced through a combination of measures dealing with the magnitude of the hazard and the community's exposure and vulnerability to it. The assessment of the extent of flooding, flood losses, and the needs of the affected communities are essential for flood relief coordination [39]. Hence, the current socio-economic conditions of the dwellers in the area are needed for 
formulating a flood management plan. Analysis of the socio-economic components of flooding helps in understanding the flooding exposure level, the characteristics of flood hazards, vulnerability patterns, and stakeholder's perceptions of flood risk.

The present study, therefore, endeavours to answer the following questions: (i) What is the socio-economic analysis of the flood impact on people residing along the banks of the river? (ii) What are the coping mechanisms adopted by the community during and after floods? (iii) How does a single flooding event change their living pattern? (iv) What are the recommendations and sustainable policy options to deal with the flooding problem in that particular area?. Overall, it is intended that the findings of the study will contribute to designing sustainable mitigation actions to manage the flooding impact and its associated risks.

\subsection{Flooding and its socio-economic impact: A review}

Socio-economic and political implications play a major role in creating more complex issues during flooding [25]. Immediate consequences are the displacement of people, loss of property and lives, and destruction of infrastructure and the surrounding environment. Flood damage assessment is important for mitigating, controlling, and preventing further flood problems, enabling interventions, and facilitating relief operations. Moreover, these actions bring methodical improvement in natural hazard areas [23]. Flood damages depend on the characteristics of flood events including the area covered, the depth and duration of flooding, the velocity and sediment content of the water, the season of occurrence, and the nature of the development [32]. The flood impact on the people of the Sikaunzwe Community in the Kazungula District of Zambia was examined by collecting both quantitative and qualitative data. The study established that poverty is the main reason for residing in a flood-prone area as there is a lack of alternative livelihoods [41].

The losses due to flooding can be estimated by collecting data based on a stagedamage curve which is combined with hydrological and land use information [31]. The cost of direct and indirect flood damage to the New South Wales town of Nyngan was assessed by conducting a property damage survey, public authority survey, survey of volunteer effort, and survey of donated goods and money. A computer model 'FLDAMAGE' was used to estimate the damage to all residential and commercial properties. Stage-damage curves were drawn based on the results of the survey [19].

Flood damage analysis using GIS was conducted by [4]. The property damage was calculated on a property by property basis and the data was analysed on a suburb by suburb basis. The methodology and procedure for risk assessment were presented and zoning of flood damage caused by heavy rainfall, based on 
the 'macro zonation concept' in which regional macro information such as meteorological triggering factors, natural and socio-economic factors contributing to flood damage, was considered [42]. An attempt was made to delineate the 1998 flood-affected city wards in Dhaka, Bangladesh into three flood damage zones based on composite damage value derived from five sectors of the city [24]. A questionnaire was prepared for collecting ward-wise damage data covering five sectors - housing, educational institutions, commercial industries, and roads. The extent of the damage was measured using the percentage of units damaged and their monetary value in local currency. Sectoral damage maps were prepared. The monetary value of flood damage was calculated in these five sectors using the Statistical Package for Social Science (SPSS). Three damage zones - low, moderate, and high were identified to help in several planning strategies.

A retrospective study in areas that suffered from floods during 2000 in China was carried out by [14] and explored the total economic loss, components of economic loss, and factors influencing economic loss during the flooding. The economic loss was calculated based on property damage, income loss, and increased medical cost [14]. 'Economic loss was significantly related to a family's pre-flood income, duration of the flood, severity of the flood, and the type of flood' [40]. The flood damage curve based on data from the recent flood event in Austria in 2006 was also estimated [28]. The maximum damage potential is identified using GIS and determines a volume - water damage function used for flood damage assessment.

The efficacy of non-structural management measures in the Thames estuary, United Kingdom was assessed by [8]. Stakeholders were engaged in developing a number of scenarios for different structural and non-structural interventions to lead changes in existing planning and insurance policies. It was identified that the efficacy of non-structural measures is sensitive to socio-economic changes and governance measures. An integrated approach which included a climate change parameter, flood inundation modelling, socio-economic analysis, and risk assessment for adaptation in the catchment of Skibhus, in the northern part of Odense, Denmark was adopted and this methodology can be an important decision-making tool in urban drainage [43].

The socio-economic impact of river floods in the European Union from the perspective of climate and socio-economic changes was evaluated by [29]. The cost/ benefits of adaptation were assessed using the outputs from climate simulations, hydrological modelling, and depth damage functions. The results highlight the necessity for flexible non-structural measures for adaptation. The 
uncertainty connected to the depth damage function used for flood damage analysis was evaluated [26] and several depth damage function formulations were selected. The historical flooding data from the Centro Storico catchment in Palermo (Italy) were then applied and the damage was evaluated using four different depth damage functions (linear, second-order polynomial, exponential, and power with upper limit functions) then compared with their results. The damages caused to vehicles and movable goods on properties were also interpolated. It was concluded that damage will be greater if there is an increase in the flooding depth.

The direct and indirect economic losses of the Po river flood during the year 2000 in Northern Italy were assessed by [6]. A methodology was developed to integrate spatial and reckonable equilibrium modelling in order to calculate the indirect impacts. Using this methodology, the pros and cons of economic effects of natural disaster for different areas in the same country were analysed. This particular methodology can be applied to other natural hazards like storm surges, forest fires, earthquakes, volcanic eruptions etc., irrespective of the region.

The relationship between water depth and the household items (furniture, goods etc) in the form of stage damage functions for the village of Pajares de Pedraza (Segovia, Spain) located in the Cega river flood plain was analysed. In order to achieve a correct estimate of fiscal losses, it is necessary to include socioeconomic and cultural circumstances existing in that area as well as the flooding type and magnitude [13].

Flood hazard maps for the Quang Ngai province, Central Vietnam for different return periods were presented. The vulnerability functions were determined from field surveys and questionnaires. The total tangible and intangible losses in the study area were also estimated and mapped. This study provides an important input to flood management plans for tropical areas similar to Quang Ngai Province [38].

FloodRisk GIS was used to analyse flood damage in an urban area of Italy. An uncertainty analysis was conducted connecting the historical damage data. The damage was quantified under different flood scenarios in order to manage flood risk. A method to compute the influence of key model parameters on the uncertainty was developed. This study highlights that having knowledge about region-specific characteristics can decrease the modelling uncertainty in the depth - damage function input parameters [1]. 
All the above studies clearly indicate that flooding cannot be avoided but the impact can be mitigated. Flood damage assessment is essential because it facilitates good decision making at the local, regional, state, and national levels of the Government for mitigation, control, and relief measures. Flood damage can be classified as both tangible and intangible [34]. The tangible damage can be further subdivided into direct and indirect damage. Direct damage results from direct contact of floodwater with damageable property and the extent of this damage is assumed to be the cost of restoration of that property to its preflood condition or its current market value if restoration is impracticable. Indirect damage is the losses caused by the disruption of physical and economic linkages, including loss of production, loss of income, loss of business, and delays in the transportation of goods. Intangible damage includes fear, anxiety, annoyance, ill health, and ultimately, loss of life. 'Flood damage depends on the characteristics of the flood event including the area covered, the depth and duration of flooding, the velocity of floodwater, the sediment content of the water, the season of the occurrence, and the nature of the development' [32].

\subsection{Studies on the Adayar river}

There have been recurrent inundations in the Adayar river floodplain (during the years 1976, 1985, 2005, 2008, and 2015) with damage to lives, property, and infrastructure. After the disastrous flooding in 1976, the Government of Tamilnadu constituted a Task Force Committee [37] to analyse the problem and suggest measures to minimize future flood damage in the region. This committee recommended flood mitigation measures such as the formation of flood protection walls, embankments, raising full tank levels of reservoirs, constructing new channels to transmit flood water, and reconstruction of bridges.

The Institute of Hydraulics and Hydrology [17] constructed a physical model of on a scale of 1/500 horizontal and 1/50 vertical and examined the discharge levels of the Adayar river during flooding. An expert committee then examined the technical problems associated with flooding in the Adayar river such as siltation, rise in flood levels due to high tides, and formation of sand bars within the riverine mouth. They concluded that flood plain zoning and then monitoring the same must be given top priority [11].

A flood hazard map of the Adayar river using Remote Sensing (RS) and a Geographic Information System (GIS) was developed by [36]. Numerical modelling of the Adayar river flooding using HEC RAS software was done by [3]. A hydrologic model using HEC geoHMS was set up and a flood inundation map for the Adayar river basin of different return periods with hypothetical 
storms was developed by [5]. This shows that there is a shift from physical model studies to more advanced techniques for forecasting flooding in real-time.

From the above studies, it is noted that they focused primarily on technical issues with flooding in the Adayar river. This study attempts to examine the socio-economic aspects of flooding in the Adayar river. Hence, the present study aims to understand the socio-economic status of the community in order to develop a stage damage curve and provide possible suggestions to minimize the flooding impact.

\section{STUDY AREA DESCRIPTION}

Riverine or fluvial floods are caused when the flow is larger than the carrying capacity of the channel causing the river to overflow on to its banks and flood the surrounding areas. One of the hot spots identified by CMDA (Chennai Metropolitan Development Authority) is along the right bank of the Adayar River near Kotturpuram. Here, the Government has provided housing for an economically weaker section of society in the flood plain area. This area has a history of flooding during the years 1976, 1985, 2005, and 2008 with damage to lives, property, and infrastructure. It is located between Latitudes $13^{\circ} 01^{\prime} 32^{\prime \prime} \mathrm{N}$ and $13^{\circ} 1^{\prime} 26^{\prime \prime} \mathrm{N}$, and Longitudes $80^{\circ} 14^{\prime} 34^{\prime \prime} \mathrm{E}$ and $80^{\circ} 14^{\prime} 21^{\prime \prime} \mathrm{E}$ and was chosen for the study of flood damage assessment due to the frequent river flooding. The index map of the area is shown in Figure 1. 


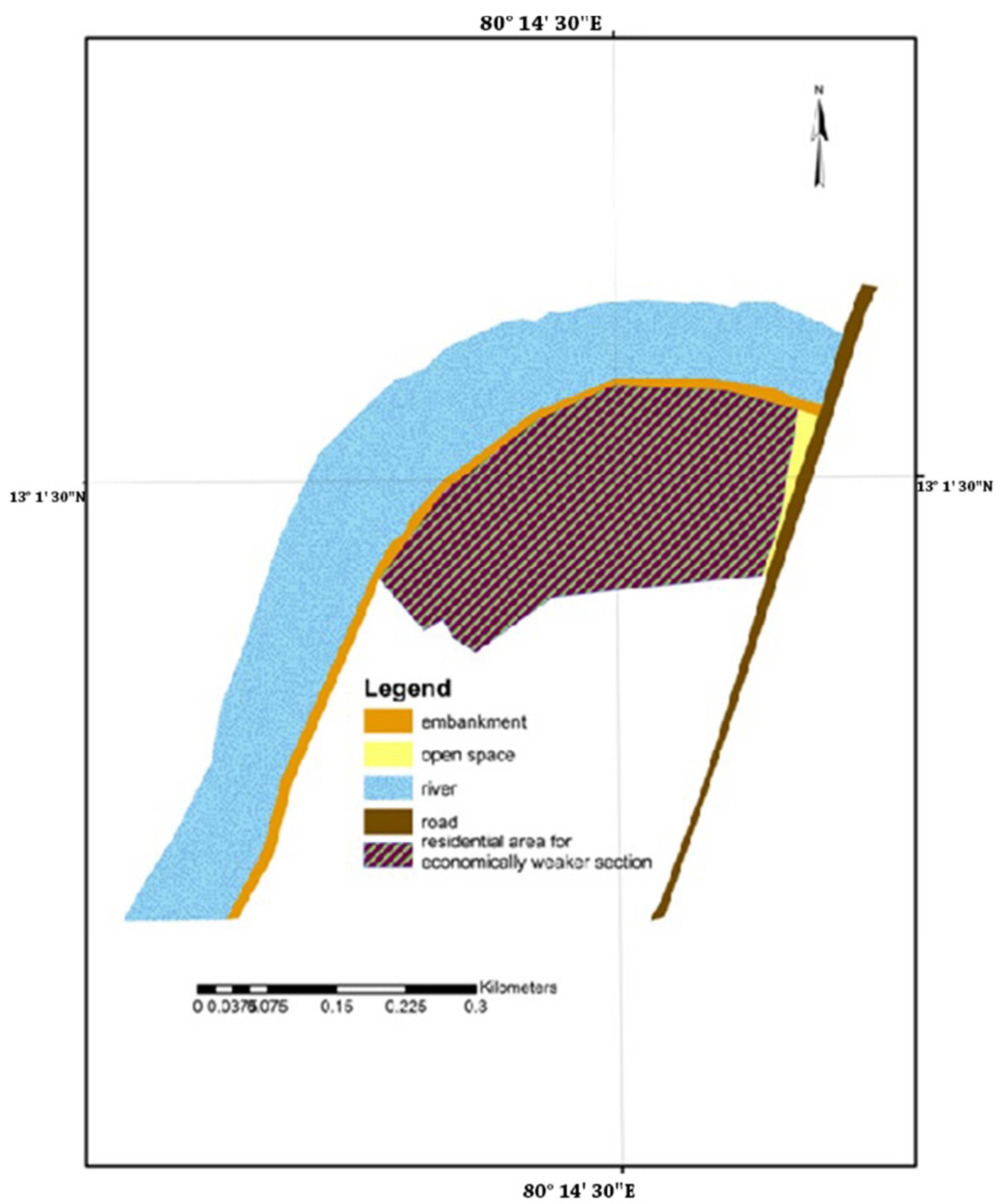

Fig. 1. Index map of the Kotturpuram Housing Board area 


\section{MATERIALS AND METHODS}

Figure 2 describes the overall methodology followed in the study. In the present study, the flood damage assessment due to inundation for the year 2015 was evaluated, taking a 165-year rainfall return period. 'Identifying the problem is a process in which we perceive and resolve a gap between a present situation and a desired goal with the path to the goal blocked by known or unknown obstacles' [15]. Therefore, this step begins with the perception of a gap and ends with the implementation and evaluation of a solution to fill that gap. A thorough analysis is required in order to identify the real problem. A clear specification of the problem is the basis for the identification of potential solutions. In the present study, the problem was identified through several different techniques, being observation, semi-structured interview, and questionnaire surveys used to identify and understand the current problem.

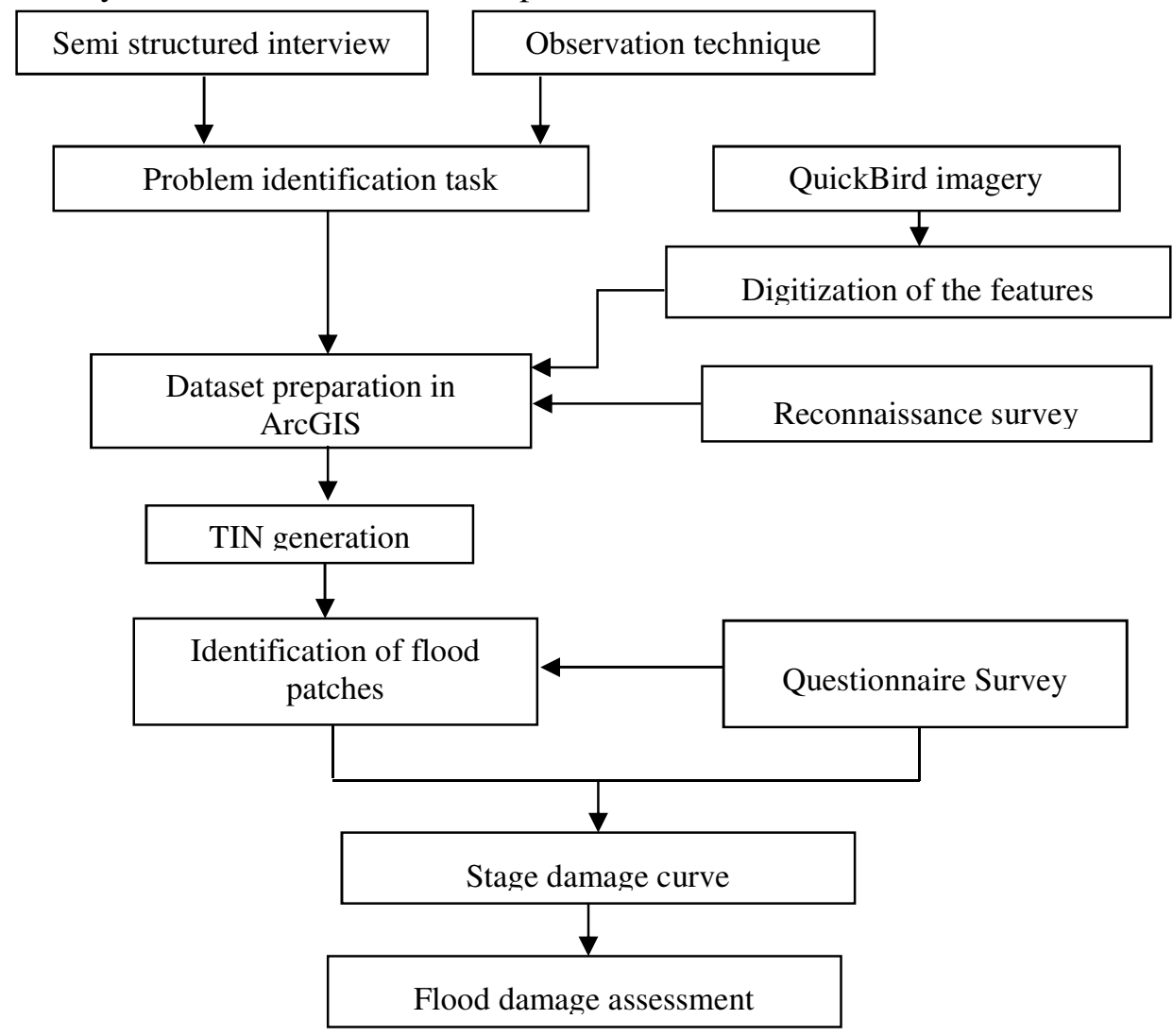

Fig. 2. Methodology flow chart 


\subsection{Observation}

The observation technique becomes a scientific method of data collection for the researcher when it serves the formulated research purpose, is planned and recorded systematically, and is subjected to proper cross-checks and controls based on validity and reliability [22]. There are two types of observation, namely, controlled observation and uncontrolled observation. If the observation takes place in the natural setting, then it is termed uncontrolled observation. If the observation takes place according to arrangements which are pre-planned, involving experimental procedure, then it is controlled observation [21]. This method will help the researcher to better comprehend the event and will also try to expose the actual conditions or problems in the study area. Frequent field visits have to be carried out in order to understand the current situation. The '4600 LS Differential GPS' was used to survey the entire reach of the river and, during the survey, elevations were recorded at different places along the riverbanks and on the bridges. The GPS readings were located on a satellite image (Google Earth Image) using Arc GIS software. Longitudinal profiles of the Adayar River from the Chembarambakkam tank to the Bay of Bengal, taken by the Public Works Department (PWD) in the year 1999 and by a Differential Global Positioning System (DGPS) survey in the year 2010, are shown in Figure 3.

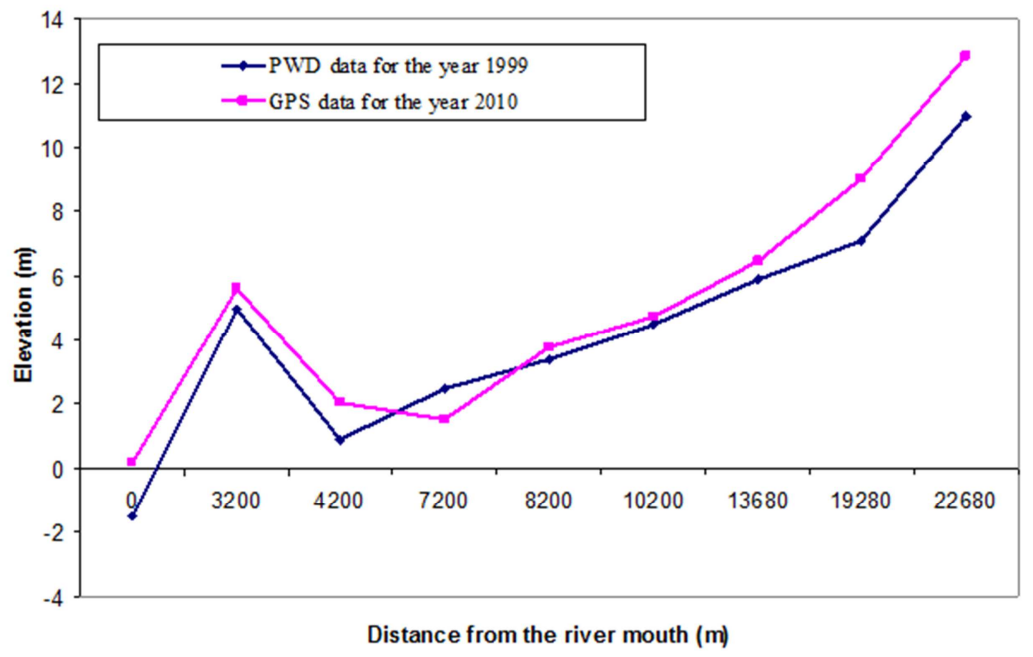

Fig. 3.Longitudinal profiles of the Adayar River from the Chembarambakkam tank to the Bay of Bengal 


\subsection{Semi-structured interview}

A semi-structured interview is a data collection method which has flexibility in asking questions to the stakeholders. The purpose of this interview was to obtain qualitative and quantitative information from the key informants. This type of interview starts with general questions and then the relevant topics are identified. All the questions are not designed and phrased before the interview. Most of the questions are created during the interview. The information obtained from the interview not only provides the answers but also the reasons for the answers. Table 1 provides a list of key informants and the focus issues discussed with them. The interview questions for the key informants are given in Appendix 1.

Table 1. Semi-structured interview with key informants

\begin{tabular}{|c|l|l|}
\hline $\begin{array}{c}\text { Sl. } \\
\text { No. }\end{array}$ & \multicolumn{1}{|c|}{ Key informants } & \multicolumn{1}{c|}{ Focus } \\
\hline 1 & CMDA officials & Land use approval \\
\hline 2 & PWD officials & $\begin{array}{l}\text { Maintenance of stormwater drains and } \\
\text { encroachment details }\end{array}$ \\
\hline 3 & $\begin{array}{l}\text { NGO representatives (Care Earth, } \\
\text { Neer Exnora, Sustain, City connect) }\end{array}$ & $\begin{array}{l}\text { Flood protection works, Awareness } \\
\text { programmes }\end{array}$ \\
\hline 4 & Welfare association & Coping situation, Flood problems \\
\hline 5 & $\begin{array}{l}\text { Academicians (Experts, } \\
\text { Institutions) }\end{array}$ & Policy recommendations \\
\hline
\end{tabular}

\subsection{Questionnaire Survey (QS)}

In the year 2015, Chennai received $539 \mathrm{~mm}$ of rainfall in December, which is almost 3 times more than the normal rainfall for this particular month [30]. Several drains overflowed and 50,000 people were evacuated from the riverbank. Following our earlier work [35], a questionnaire was prepared for collecting damage data covering four aspects - general information, information about the flood, flood damage assessment, and flood management. In the general information, demographic details and data on annual income and housing typology were collected. Details of the cause of flooding, problems faced by people due to flooding, outflows of flood water, water stagnation period, and area of inundation in their house were the also collected. Information on property damage and the recovery cost, daily wage loss, and the additional amount spent during flooding were also collected to assess the flood damage. For flood management, coping strategies, measures taken to limit future flood loss, and their suggestions to minimize the effect of flooding were also collected. For this survey, every 3rd block was chosen out of 84 blocks and a total of 27 
blocks (one house each on the ground floor and first floor) were surveyed. This technique is called 'Systematic sampling' and this procedure was used because the sampling frame was available in the form of blocks.

\subsection{Flood Damage Assessment}

A reconnaissance survey was carried out to gather preliminary information about the flood-affected areas of Kotturpuram. It was found that all the 84 blocks were affected and all the ground floor houses were fully submerged due to floods. Therefore, both the ground floor and first floor of a block were surveyed. Second and third floors were not taken into consideration because they were not affected to the same degree as the ground and first-floor dwellings.

GIS (Geographic Information System) based software applications were used in this study to handle and examine the large volume of spatial and non- spatial data. The QuickBird Imagery of the study area was digitized, and the contour map of the study area was overlaid. Information about the flood spread area was collected from the Questionnaire Survey. TIN, a vector-based representation of the land surface or submerged areas, made up of irregularly distributed nodes and lines with three-dimensional coordinates (x, y, and $\mathrm{z}$ ) arranged in a network of non-overlapping triangles, was generated. Based on the information collected from the survey, the extent of flooding was identified and digitized. SPSS 15 (Statistical Package for Social Sciences), was used to analyse both qualitative and quantitative data collected from the survey, and the Master Table was then prepared. In the Master Table, the rows were considered to be the observational units and the columns were considered to be variables for the observational units. Simple statistical analysis such as mean, median, mode, $\min / \max$ values were performed using the Master Table.

A stage damage curve for the inundated area was obtained based on the information collected from the questionnaire survey. "A stage damage curve is also referred to as "flood loss function" and depicts the relationship of damage as it varies with flood depth' [20]. The stage damage curve can be used for estimating the damage under different flood depths of individual blocks. After completing the questionnaire surveys, the samples were categorized into two groups, namely Group I (households with property damage) and Group II (households without property damage) based on the experience of flood impact.

Total cost of flood for group $\mathrm{I}=$ Additional amount spent during flood (transport, consumable items, etc.) + Replacement cost

Total cost of flood for group II = Additional amount spent during flood Thus, the total flood cost incurred by both Group I and II is identified. 


\section{RESULTS AND DISCUSSIONS}

\subsection{Socio-Economic analysis}

Socio-economic analysis was carried out in order to assess the flood damage. After analysing the responses to the questionnaire survey in SPSS, it was found that the annual average income of the people varied from Rs. 50,000 to 100,000 (1 USD = Rs.65 approx.) in the year 2015. $13 \%$ of the people were graduates. $87 \%$ had completed schooling. Due to sediment deposits on the Adyar river, an average of about 5 people every year are trapped in the Adayar Riverbed near Kotturpuram Bridge (situated at the chainage $2.5 \mathrm{~km}$ from the river mouth). This is due to excessive sediments being deposited, which in turn increases the depth of flooding. The total number of blocks in the Kotturpuram Housing Board area is 84 ( 24 blocks of 8 houses each, 2 houses on the ground floor plus 6 houses in three storeys above, and 60 blocks of 6 houses each, 2 houses on the ground floor plus 4 houses in two storeys above). The total number of blocks surveyed is 27 (7 in three-storey buildings and 20 in two-storey buildings). From the analysis, it was found that all the dwellings on the ground floor in all 84 blocks had undergone property damage. The people on the ground floor moved to the first floor with their belongings and stayed with the first-floor occupants for about 5 days. They cooked and lived together in a $237 \mathrm{sq} f t$ flat. The flooding depth varied between $0.5 \mathrm{~m}$ to $6.01 \mathrm{~m}$. The suggestions given by the people to minimize the effect of flooding are to remove the debris from the river, increase the embankment height, and provide proper drainage facilities. The socioeconomic characteristics of the community vulnerable to riverine flooding are listed in Table 2, the respondents' estimates of flood problems are given in Table 3. Figure 4 shows the TIN of Kotturpuram Housing Board area. 
Table 2. Socio-economic details of the Kotturpuram Housing Board area

\begin{tabular}{|c|c|c|}
\hline Sl. No. & Category & Riverine flooding \\
\hline 1 & No of respondents & 54 \\
\hline 2 & Sampling technique & $\begin{array}{l}\text { Strategic sampling } \\
\text { (block wise) }\end{array}$ \\
\hline 3 & 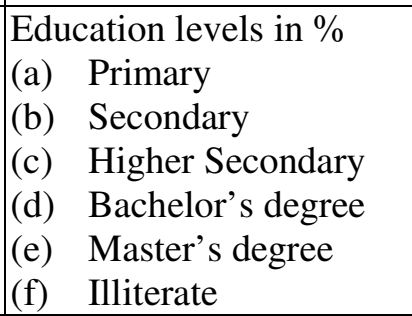 & $\begin{array}{r}11 \\
43 \\
33 \\
7 \\
2 \\
4\end{array}$ \\
\hline 4 & 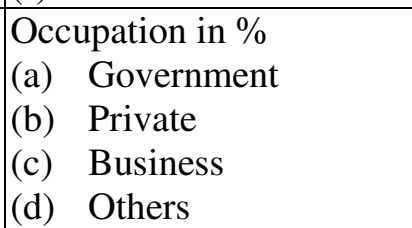 & $\begin{array}{r}0 \\
58 \\
22 \\
20\end{array}$ \\
\hline 5 & $\begin{array}{l}\text { Annual income (Rs) in \% } \\
\text { (a) }<50000 \\
\text { (b) } 50001 \text { to } 100000 \\
\text { (c) } 100001 \text { to } 500000 \\
\text { (d) } 500001 \text { to } 1000000 \\
\text { (e) }>1000000\end{array}$ & $\begin{array}{r}40 \\
54 \\
6 \\
0 \\
0\end{array}$ \\
\hline 6 & 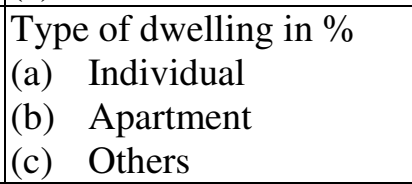 & $\begin{array}{r}0 \\
0 \\
100\end{array}$ \\
\hline 7 & $\begin{array}{l}\text { Ownership details in \% } \\
\text { (a) Owner } \\
\text { (b) } \text { Tenant } \\
\text { (c) } \text { Lease }\end{array}$ & $\begin{array}{r}69 \\
31 \\
0\end{array}$ \\
\hline
\end{tabular}



DWELLINGS: ADAYAR RIVER, A CASE STUDY

Table 3. Respondents' estimates of flood problems

\begin{tabular}{|c|l|c|c|c|}
\hline Sl. No. & \multicolumn{1}{|c|}{ Flood characteristics } & $\begin{array}{c}\text { Standard } \\
\text { deviation } \\
(\mathrm{N}=54)\end{array}$ & Minimum & Maximum \\
\hline 1 & $\begin{array}{l}\text { Frequency of flooding in a year } \\
\text { (no of times })\end{array}$ & 0 & 1 & 1 \\
\hline 2 & Inundated period in days & 0 & 5 & 5 \\
\hline 3 & Depth of flooding in $\mathrm{m}$ & 2.4 & 0.5 & 6.01 \\
\hline
\end{tabular}

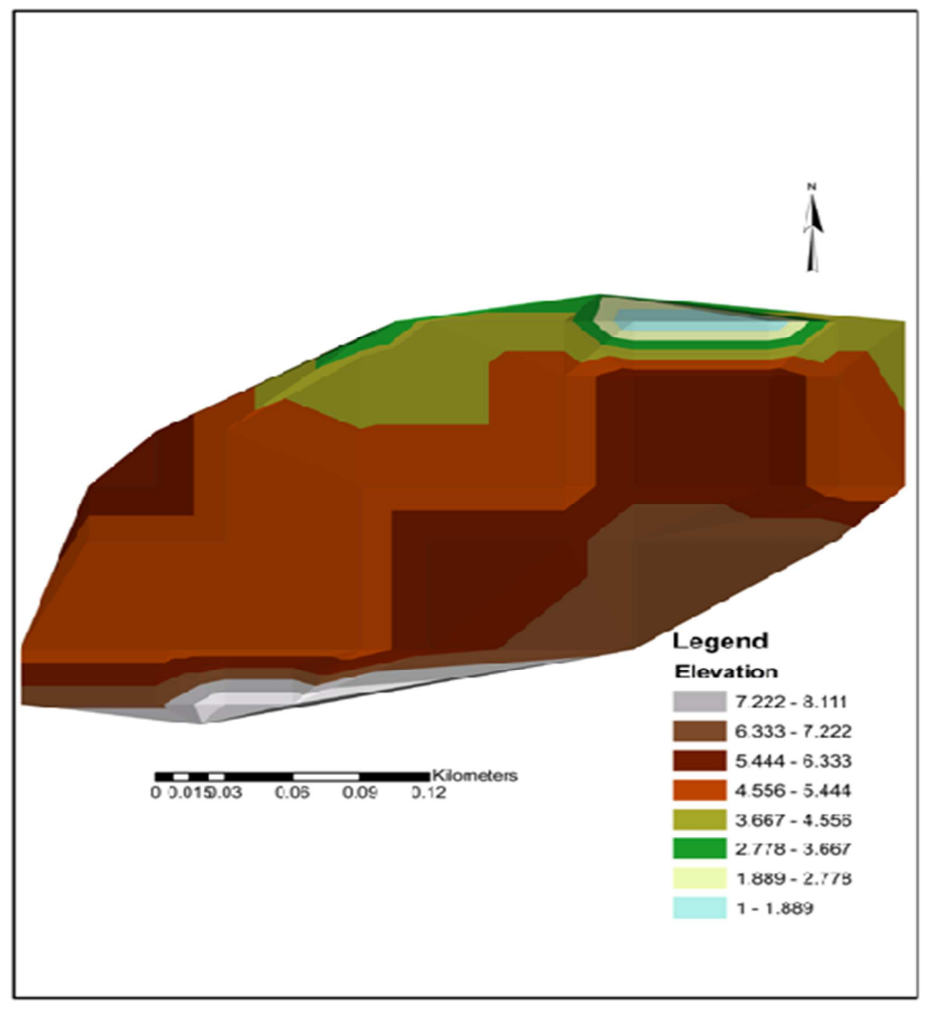

Fig. 4. TIN of Kotturpuram Housing Board area 


\subsection{Questionnaire Survey results}

Table 4. shows the replacement costs incurred by Group I.

Table 4. Replacement costs incurred by Group I in Kotturpuram Housing Board Area

\begin{tabular}{|c|l|c|c|}
\hline $\begin{array}{c}\text { Sl. } \\
\text { No. }\end{array}$ & Property damage & No of households & $\begin{array}{c}\text { Replacement cost } \\
(\mathrm{Rs})\end{array}$ \\
\hline 1 & House & 24 & $2,40,000$ \\
\hline 2 & Furniture & 17 & 51,000 \\
\hline 3 & Tv and Fridge & 22 & $1,10,000$ \\
\hline 4 & Vehicle & 22 & $1,76,000$ \\
\hline 5 & Miscellaneous & 22 & 50,000 \\
\hline 6 & \multicolumn{2}{|c|}{ Total replacement cost } & $6,27,000$ \\
\hline
\end{tabular}

The stage damage curve shown in Figure 5 was constructed to derive the relationship between flood damage and flood depth, using data collected from the field survey and can be used to estimate damage/household under different flood depths in the study area. The information about damage to the assets under different flood depths was also collected from the survey. It can be observed from the graph that the ground floor of the apartments is fully submerged if the flooding is greater than $3.5 \mathrm{~m}$.

The details of the amounts spent by people during the floods for transportation and health are shown in Table 5. Flood cost (without considering the expenses during a normal period) for 27 households in Group I is Rs 20,800, while the flood cost (health, water, and milk) for 27 households in Group II is Rs 14,300. 


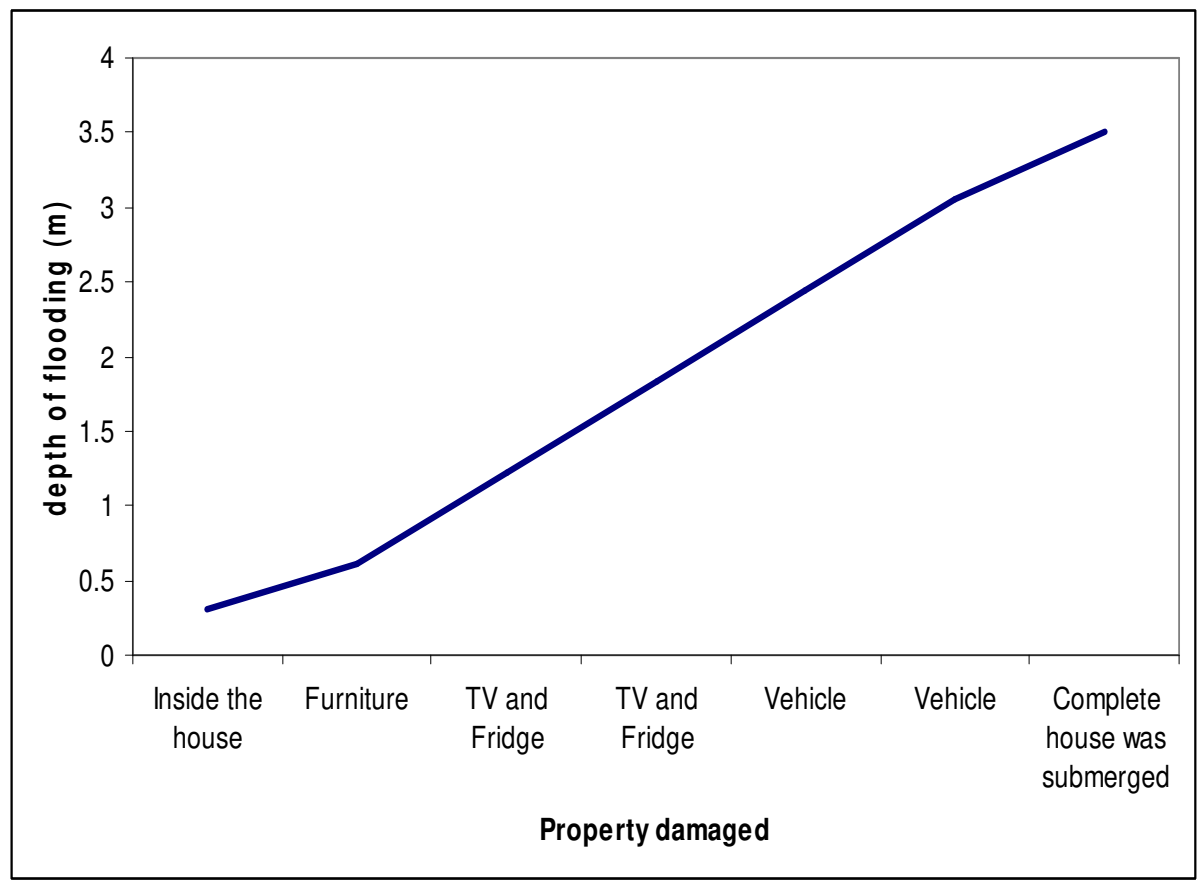

Fig. 5. Stage damage curve for the Kotturpuram Housing Board area

Table 5. Comparative table for the amount spent during normal and flood times in the Kotturpuram Housing Board area

\begin{tabular}{|c|c|l|r|r|}
\hline \multirow{2}{*}{ Sl. No. } & \multicolumn{2}{|c|}{ Content } & \multicolumn{2}{c|}{ Amount spent (Rs) } \\
\cline { 3 - 5 } & \multirow{2}{*}{1} & Normal & \multicolumn{1}{c|}{ Group I } & \multicolumn{1}{c|}{ Group II } \\
\cline { 3 - 5 } & \multirow{2}{*}{ Water } & Flood & 3,376 & 2,376 \\
\hline \multirow{2}{*}{2} & \multirow{2}{*}{ Health } & Normal & 1,500 & 3,100 \\
\cline { 3 - 5 } & & Flood & 15,500 & 1,500 \\
\hline \multirow{2}{*}{3} & \multirow{2}{*}{ Milk } & Normal & 6,000 \\
\cline { 3 - 5 } & \multirow{2}{*}{4} & Flood & 2,200 & 2,200 \\
\hline \multirow{2}{*}{4} & Total & Normal & 4,551 & 4,551 \\
\cline { 3 - 5 } & & Flood & 20,800 & 14,300 \\
\hline
\end{tabular}

A summary of Tables 4 and 5 is provided in Table 6, which is the aggregated flood (damage) cost. 
Table 6. Total damage assessment of the Kotturpuram Housing Board area

\begin{tabular}{|c|l|c|c|c|}
\hline S1. No. & \multicolumn{1}{|c|}{ Flood cost/problem } & $\begin{array}{c}\text { No of } \\
\text { households } \\
\text { surveyed }\end{array}$ & $\begin{array}{c}\% \text { of } \\
\text { households }\end{array}$ & $\begin{array}{c}\text { Total loss } \\
\text { (Rs) }\end{array}$ \\
\hline 1 & $\begin{array}{l}\text { Property damage (only the } \\
\text { ground floor) }\end{array}$ & 24 & 44.4 & $6,27,000$ \\
\hline 2 & Water & 54 & 100 & 1,448 \\
\hline 3 & Health & 54 & 100 & 21,500 \\
\hline 4 & Milk & 54 & 100 & 3,050 \\
\hline 5 & Loss of daily wages & 54 & 100 & 16,200 \\
\hline 6 & \multicolumn{3}{|c|}{ Total flood cost } & $6,69,198$ \\
\hline
\end{tabular}

Total money spent during flood by Group I

$=\operatorname{Rs} 6,51,349$

$[6,27,000+(20,800-4,551)+(16,200 / 2)]$

Total money spent during flood by Group II

$=\quad \operatorname{Rs} 17,849$

$[(14,300-4,551)+(16,200 / 2)]$

No of households which come under group I

$=168$

No of households which come under group II

$=384$

Total cost spent during flood by 168 households

$=$ Rs 40,52,838

Total cost spent during flood by 1 household (Group I) =

$=\quad$ Rs 24, 124

Total cost spent during flood by 384 households $=$ Rs 2, 53, 852

Total cost spent during flood by 1 household (Group II) $=$ Rs 661

The total cost spent by 552 households

$=$ Rs 43, 06, 690

The inundated area is found to be $79866 \mathrm{~m}^{2}$. The average cost during flooding for one household in Group I and Group II (based on an average of 5 persons) is Rs 24,124 and Rs 661, respectively.

\subsection{Rescue and relief operations}

Government, defence agencies, non-governmental organizations, along with many volunteers (individuals of all age groups and across all professions) joined together by distributing food packets, water bottles, and essential amenities to the victims during the rescue period. Despite cultural differences, all the temples, churches, mosques, shopping malls, and even cinemas and theatres were opened to flood victims [12]. Social media was used for awareness 
generation. The government engaged nearly 25,000 sanitary workers to clean stacked garbage in order to prevent the spreading of diseases [16]. The outbreak of disease was controlled by mobile medical camps and timely actions taken by the Department of Health \& Family Welfare of the state government and also by other voluntary organizations [2]. State government distributed bleaching powder packets to households as well as spreading the powder on the streets.

\section{CONCLUSIONS AND RECOMMENDATIONS}

A stage damage curve has been built for the residential sector of the Kotturpuram Housing Board area and can be used extensively for flood damage assessment as well as damage mitigation. The stage damage curves were derived from the data collected for the study area. In the socio-economic analysis, the physical characteristics such as land use data, existing building types in the area, and the social and economic characteristics of the people residing in the area were considered for the Kotturpuram Housing Board area. Economic investigations are oriented towards the flood damage assessment of the area and the stage damage curves developed for the area.

(i) In the Kotturpuram Housing Board area located on the right bank of the Adayar River, the depth of flooding is about $6 \mathrm{~m}$ and the inundated area is found to be $79866 \mathrm{~m}^{2}$.

(ii) Stage damage curves were constructed for the residential sectors of the Kotturpuram Housing Board area which can be used extensively for flood damage assessment. The stage damage curves were derived from the primary data collected in the study area through a questionnaire survey. These data may be site-dependent.

(iii) Through the observation technique, it was found that the bed level of the river is undulating with portions having adverse gradients (between the chainages at $2.2 \mathrm{~km}$ and $4.2 \mathrm{~km}$ from the mouth of the river). At a chainage of $2.5 \mathrm{~km}$, near the Kotturpuram Bridge, the bed level has increased from $5 \mathrm{~m}$ in 1999 to $5.8 \mathrm{~m}$ in 2010 . A separate hydraulic study can be conducted using the hydraulic model (HEC- RAS) to check the possibility of channel improvement.

(iv) As more and more silt is deposited due to littoral drift, the mouth of the river is chocking, resulting in the overflow of the riverbanks, a higher frequency of inundation, and continued siltation. Therefore, 
it is suggested that channel improvement works such as clearing the sand bar at the mouth of the river and maintaining a uniform bed slope from the Kotturpuram Bridge to the river mouth will reduce the flooding and enhance river flushing activity which in turn will rejuvenate the river.

\section{APPENDIX 1}

\section{SEMI - STRUCTURED INTERVIEW}

The semi-structured interview was conducted with Government officials (Chennai Metropolitan Development Authority (CMDA), Public Works Department (PWD) and Corporation of Chennai), Academicians, Welfare Associations, and NGO representatives. The sharing of information was twoway between the researcher and the officials.

\section{A.1.1 PWD OFFICIALS}

1) Maintenance of river

2) How long have you been working as an engineer on this river?

3) What was the condition of the river ten years ago, twenty years, etc.?

4) Repair of damaged structures

5) Are you aware of sewage disposal in the river?

6) If yes, what actions have you taken to stop the sewage disposal?

7) Whether all the encroachments have been removed?

8) Building of infrastructure (flood)

9) Maintenance of infrastructure (lock)

10) Whether there is any obstruction of flow due to MRTS construction?

11) How often do you measure discharge data? (monsoon/nonmonsoon)

12) Future plans to improve the river

\section{A.1.2 CMDA}

1) Land use approval

2) Enforcement of proper land use planning

3) Knowledge of drainage conditions

4) Budget allocations for flood mitigations 


\section{A.1.3 WELFARE ASSOCIATIONS}

1) Distributing relief supplies to flood victims

2) Search and rescue for people from flood-affected area

3) Coping strategy

4) Problems faced by them

\section{A.1.4 NGO REPRESENTATIVES}

1) How do they create awareness among the local people?

2) What was the response of these people?

3) Problems faced by them

4) Relationship with media and government

\section{A.1.5 ACADEMICIANS}

1) Policy recommendations

2) Technical support for flood management

3) Plans to minimize the effects of flooding

\section{REFERENCES}

1. Albano, R, Sole, A, Adamowski, J, Perrone, A and Inam, A 2018. Using FloodRisk GIS freeware for uncertainty analysis of direct economic flood damages in Italy. International Journal of Applied Earth Observation and Geoinformation 73, 220 - 229.

2. Amalorpavanathan, J, Ramakumar, M and Sivasubramanian, S 2016. Preparedness in Disaster Situations Lessons from Chennai Floods 2015. Economic \& Political Weekly 1, 30 - 34.

3. Arivazhan, R, Sureshraj, RI, Thenmozhi, E, Bhuvaneshwari, B and Vishnu, N 2019. Numerical modeling of Adyar river. International Journal of Recent Technology and Engineering (IJRTE) 8, 6965 6970.

4. Betts H, 2002 Flood damage analysis using GIS: Gold Coast City Capital. Australian Journal of Emergency Management, 33 - 37.

5. Brema, J 2020. Flood modeling and Mapping: Case study on Adyar River Basin, Chennai, India. In Decision Support Methods for Assessing flood risk and Vulnerability edited by Ahmed Karmaoui, 104 - 139, Hershey, PA: IGI Global, http://doi:10.4018/978-1-52259771-1.ch006.

6. Carrera, L, Standardi, G, Bosello, F and Mysiak, J 2015. Assessing direct and indirect economic impacts of a flood event through the 
integration of spatial and computable general equilibrium modeling. Environmental Modelling and Software 63, 109 - 122.

7. Carter, WN 2008. Disaster Management - Disaster Managers' Handbook. Manila, Philippines: Publication of the Asian Development Bank, ISBN 978-971-561-006-3.

8. Dawson, RJ, Ball, T, Werrity, J, Werritty, A, Hall, JW and Roche, N 2011. Assessing the effectiveness of non-structural flood management measures in the Thames Estuary under conditions of socio-economic and environmental change. Global Environmental change 21, $628-646$.

9. Dhiman, R, Vishnuradhan, R, Eldho, TI, Inamdar, A 2018. Flood risk and adaptation in Indian coastal cities: recent scenarios, Applied Water Science 9:5, https://doi.org/10.1007/s13201-018-0881-9.

10. Eum, H, Sredojevic, D and Simonovic, SP and ASCE, F 2011. Engineering procedure for the climate change flood risk assessment in the upper Thames river basin. Journal of Hydrologic Engineering 16, $608-612$.

11. Expert committee report 1986. Flood protective works in Adayar river by Government of Tamil Nadu, Public Works Department.

12. Frontline 2015. http://www.frontline.in/cover-story/sunk-bynegligence/article7965695 .ece.

13. Garrote, J, Alvarenga, FM and Diez-Herrero, A 2016. Quantification of flash flood economic risk using ultra-detailed stage-damage functions and 2-D hydraulic models. Journal of Hydrology 541, 611 -625 .

14. Huang, $X$ et al. 2008. Flood hazard in Hunan Province of China: an economic loss analysis. Natural Hazards, $65-73$.

15. Huitt, WG 1992. Problem-solving and decision making: Consideration of individual differences using the Myers - Briggs type indicator. Journal of Psychological Type 24, 33 - 44.

16. IBN Live 2015. http://www.news18.com/news/india/as-waterrecedes-chennai-braces-tocheck-outbreak-of-diseases-1174026.html.

17. Institute of Hydraulics and Hydrology report No. 4/86 1981. Report on proposed flood protection works for Adayar study of its effect on flood flow characteristics through model technique.

18. IPCC 2007 Climate change 2007; Synthesis report, An assessment of the intergovernmental panel on climate change. 
19. Joy, CS 1993. The cost of flood damage in Nyngan. Climate Change 25, $335-351$.

20. Kang, JL, Su, MD and Chang, LF 2005. Loss functions and framework for regional flood damage estimation in a residential area. Journal of marine science and technology 13, 193 - 199.

21. Kothari, CR 2004. Research methodology methods and techniques. Second revised edition, New Age International Publishers, New Delhi.

22. Kumar, RC 2008. Research Methodology, APH publishing corporation, New Delhi.

23. Merz, B, Kreibich, H, Schwarze, R and Thieken, A 2010. Review article assessment of economic flood damage. Natural Hazards and Earth System Science 10, 1697 - 1724.

24. Mohit, MA and Akther, S 2002. Delineation of flood-damaged zones of Dhaka city based on the 1998 flood by using GIS. Engineering concerns of flood, Published by BUET, ISBN $984-823-002-5$, $303-318$.

25. Mwape, PY 2009. An impact of floods on the socio-economic livelihoods of people: A case study of Sikaunzwe community in Kazungula district of Zambia, Mini dissertation submitted to the University of the Free State, Disaster risk management training and education centre for Africa.

26. Notaro, V, De Marchisa, M, Fontanazzaa, CM, La Loggiab, G, Puleob, V and Frenia, G 2014. The effect of damage functions on urban flood damage appraisal, Procedia Engineering 70, 1251 1260.

27. Parkinson, J and Mark, O 2005. Urban stormwater management in developing countries, First edition, IWA publishing, London SW, UK.

28. Prettenthaler, F, Amrusch, $\mathrm{P}$ and Habsburg-Lothringen, C 2010. Estimation of an absolute flood damage curve based on an Austrian case study under a dam breach scenario. Nat. Hazards Earth Syst. Sci 10, 881 - 894 .

29. Rojas, R, Feyen, L and Watkiss, P 2013. Climate change and river floods in the European Union: Socio-economic consequences and the costs and benefits of adaptation, Global Environmental Change 23, $1737-1751$. 
30. Skymet

weather

2015.

https://www.skymetweather.com/content/weather-news-and-

analysis/heavy-chennai-rains-remind-residents-of-2015-floods/

31. Smith, DI 1981. Actual and potential flood damage: a case study for urban Lismore, NSW, Australia. Applied Geography 1, 31 - 39.

32. Soetanto, R and Proverbs, DG 2004. Impact of flood characteristics on damage caused to UK domestic properties: The perceptions of building surveyors. Journal of Structural Survey 22, 95 - 104.

33. SREX report 2012. Managing the risks of extreme events and disasters to advance climate change adaptation special report of the Intergovernmental panel on climate change, Cambridge University Press,ISBN978-1-107-02506-6, www.ipcc.ch/site/assets/uploads/2018/03/SREX_Full_Report-1.pdf

34. Stormwater drainage assessment report 2018. Prepared for Victorian planning authority https://vpa-web.s3.amazonaws.com/wpcontent/uploads/2018/10/East-Village-Drainage-Report-CardnoSeptember-2018.pdf

35. Suriya, S, Mudgal, BV and Prakash Nelliyat 2012. Flood damage assessment of an urban area in Chennai, India , part I: methodology. Natural Hazards 62, 149 - 167.

36. Suriya, S and Mudgal BV 2016. GIS based flood hazard mapping of Adyar watershed, Chennai, India, Proceedings of Annual International Conference on Architecture and Civil Engineering, DOI : 10.5176/2301-394X ACE16.42

37. Task force committee report 1976. Floods in Madras November 1976 - Report of the committee constituted by government to study the floods in November 1976.

38. Vu, TT and Ranzi, R 2017. Flood risk assessment and coping capacity of floods in central Vietnam, Journal of Hydro-environment Research 14, $44-60$.

39. WMO 2007. Conducting flood loss assessments, APFM Technical Document No.7, Flood management tools series, http://www.apfm.info/pdf/ifm_tools/Tools_Flood_Loss_Assessment. pdf.

40. Xin, $\mathrm{H}$ et al. 2008. Flood hazard in Hunan province of China: An economic loss analysis, URI: http://197.255.68.203/handle/123456789/984 
41. Yande, P 2009. An impact of floods on the socio-economic livelihoods of people: A case study of Sikaunzwe community in Kazungula district of Zambia. A master's thesis submitted to faculty of natural and agricultural sciences, University of the free state, Africa.

42. Zhang, J, Okada, N, Tatano, H and Hayakawa, S 2002. Risk assessment and zoning of flood damage caused by heavy rainfall in Yamaguchi Prefecture, Japan. Flood Defence '2002, Science Press, New York Ltd, ISBN 7 - 03 - $008310-5,162-169$.

43. Zhou, Q, Mikkelsen, PS, Halsnaes, K and Arnbjerg-Nielsen, K 2012. Framework for economic pluvial flood risk assessment considering climate change effects and adaptation benefits, Journal of Hydrology 414- 415, 539 - 549.

Editor received the manuscript: 10.05.2020 